\title{
A case of a giant cell myocarditis that developed massive left ventricular thrombus during percutaneous cardiopulmonary support
}

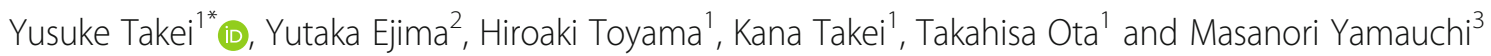

\begin{abstract}
Background: Giant cell myocarditis, characterized by infiltration of multinucleated giant cells in the myocardium, is a rare type of myocarditis. It often progresses rapidly into fulminant heart failure and indicates a poor prognosis. When a patient with giant cell myocarditis develops into severe myocarditis presenting with a cardiogenic shock, we should use a percutaneous cardiopulmonary support (PCPS), which could occur complications. We experienced a patient with giant cell myocarditis, who developed left ventricular thrombus formations during the circulation support therapy with PCPS for cardiogenic shock.
\end{abstract}

Case presentation: A 60-year-old man who developed a cardiogenic shock was transferred to our hospital. After the admission, inotropic agents were increased and an intra-aortic balloon pumping was started. But these therapies did not improve his hemodynamic status. He was placed PCPS. Then, he underwent endomyocardial biopsy and was diagnosed with giant cell myocarditis. On the next morning, he developed complete atrioventricular block, and subsequently, thrombus formations occurred in his left ventricular outlet tract and Valsalva sinus despite an anticoagulant therapy. Thereafter, we intensified the anticoagulant therapy to prevent further thrombus formation, but he developed an intracranial hemorrhage. He did not recover from heart failure and died 16 days after the admission.

Conclusions: We present a patient with giant cell myocarditis who developed widespread thrombosis in the left ventricle during the circulatory support with PCPS, despite anticoagulant therapy. In this case, decreased left myocardial contractility caused by giant cell myocarditis and increased left ventricular afterload by the retrograde perfusion from the PCPS induced the thrombotic tendency and congestion in the left ventricle. In addition, he developed complete atrioventricular block, which reduced the left ventricular ejection and enhanced the thrombus formation. Because patients with giant cell myocarditis have a low probability of spontaneous recovery, heart transplantation or ventricular assist device implantation may be required for circulatory support. We should establish mechanical circulatory support rapidly to improve the prognosis of patients with giant cell myocarditis. Moreover, a ventricular assist device, which can prevent both ventricular congestion and retrograde blood flow, might be suitable to prevent complications as this case.

Keywords: Giant cell myocarditis, Ventricular thrombus, Percutaneous cardiopulmonary support system

\footnotetext{
* Correspondence: y-takei@xf7.so-net.ne.jp

'Department of Anesthesiology, Tohoku University Hospital, 1-1 Seiryomachi,

Aoba-ku, Sendai 980-8574, Japan

Full list of author information is available at the end of the article
} 


\section{Background}

Giant cell myocarditis, characterized by infiltration of multinucleated giant cells in the myocardium, is a rare type of myocarditis. Fulminant myocarditis can occur during its clinical course. When it occurs, prognosis is extremely poor due to acute heart failure [1-4]. Herein, we report a patient with giant cell myocarditis who developed massive left ventricular thrombus during the circulatory support with percutaneous cardiopulmonary support (PCPS) for the treatment of progressive heart failure.

\section{Case presentation}

A 60-year-old man noted cold-like symptoms. After a month, he was visited to a local hospital and was suspected with myocarditis because his blood examination showed high inflammatory reactions and his echocardiogram showed severe cardiac dysfunction. He was started on intravenous continuous infusions of dobutamine $(5 \mu \mathrm{g} / \mathrm{kg} / \mathrm{min})$ and dopamine $(5 \mu \mathrm{g} / \mathrm{kg} / \mathrm{min})$ and transferred to our hospital. Upon admission to the intensive care unit, his consciousness, heart rate, blood pressure, arterial oxygen saturation level $(5 \mathrm{~L} / \mathrm{min}$ of supplemental oxygen via facemask), and body temperature were clear, $105 \mathrm{bpm}, 105 / 66 \mathrm{mmHg}, 100 \%$, and $38.2{ }^{\circ} \mathrm{C}$, respectively. His chest radiograph and chest computed tomography showed pulmonary congestion and bilateral pleural effusion without cardiomegaly, and the electrocardiogram showed low voltage of R-wave and intraventricular conduction disturbance in all leads (Fig. 1). His laboratory examination showed inflammatory reaction, elevated levels of cardiac enzyme, and serum brain natriuretic peptide but almost normal range of coagulation (Table 1). His transthoracic echocardiogram showed a significant decrease in the myocardial contractility of the both ventricles but did not show the enlargement of both ventricles and a thrombus formation in all ventricles. Right cardiac catheterization, under the continuous infusions of dopamine $(5 \mu \mathrm{g} / \mathrm{kg} / \mathrm{min})$ and dobutamine $(5 \mu \mathrm{g} / \mathrm{kg} / \mathrm{min})$, showed that cardiac output (CO), pulmonary arterial pressure (PAP), pulmonary arterial wedge pressure, and mixed venous oxygenation saturation $\left(\mathrm{S}_{\mathrm{v}} \mathrm{O}_{2}\right)$ were $3.60 \mathrm{~L} / \mathrm{min}, 37 / 18(26) \mathrm{mmHg}$, $26 \mathrm{mmHg}$, and $40 \%$, respectively, which indicated cardiogenic shock and post-capillary pulmonary hypertension (Table 2). Coronary angiography showed no abnormal findings. Because he was diagnosed with myocarditis and refractory to inotropic agents, he was inserted with intraaortic balloon pumping (IABP). Despite $6 \mathrm{~h}$ of IABP support, his hemodynamic status progressively deteriorated; hence, we decided to start the mechanical ventilation and mechanical circulatory support by a PCPS on him. We administered $1 \mathrm{mg}$ of midazolam, $0.2 \mathrm{mg}$ of fentanyl, and $50 \mathrm{mg}$ of rocuronium, performed endotracheal intubation, and started the airway pressure release ventilation with fraction of inspired oxygen $\left(\mathrm{F}_{\mathrm{I}} \mathrm{O}_{2}\right)$ of 0.6 , the high continuous airway pressure (CPAP) of $20 \mathrm{cmH}_{2} \mathrm{O}$, duration of high CPAP of $9.5 \mathrm{~s}$, low CPAP of $0 \mathrm{cmH}_{2} \mathrm{O}$, and duration of low CPAP of $0.5 \mathrm{~s}$ in order to avoid the lung collapse. In this setting, his minute ventilation volume

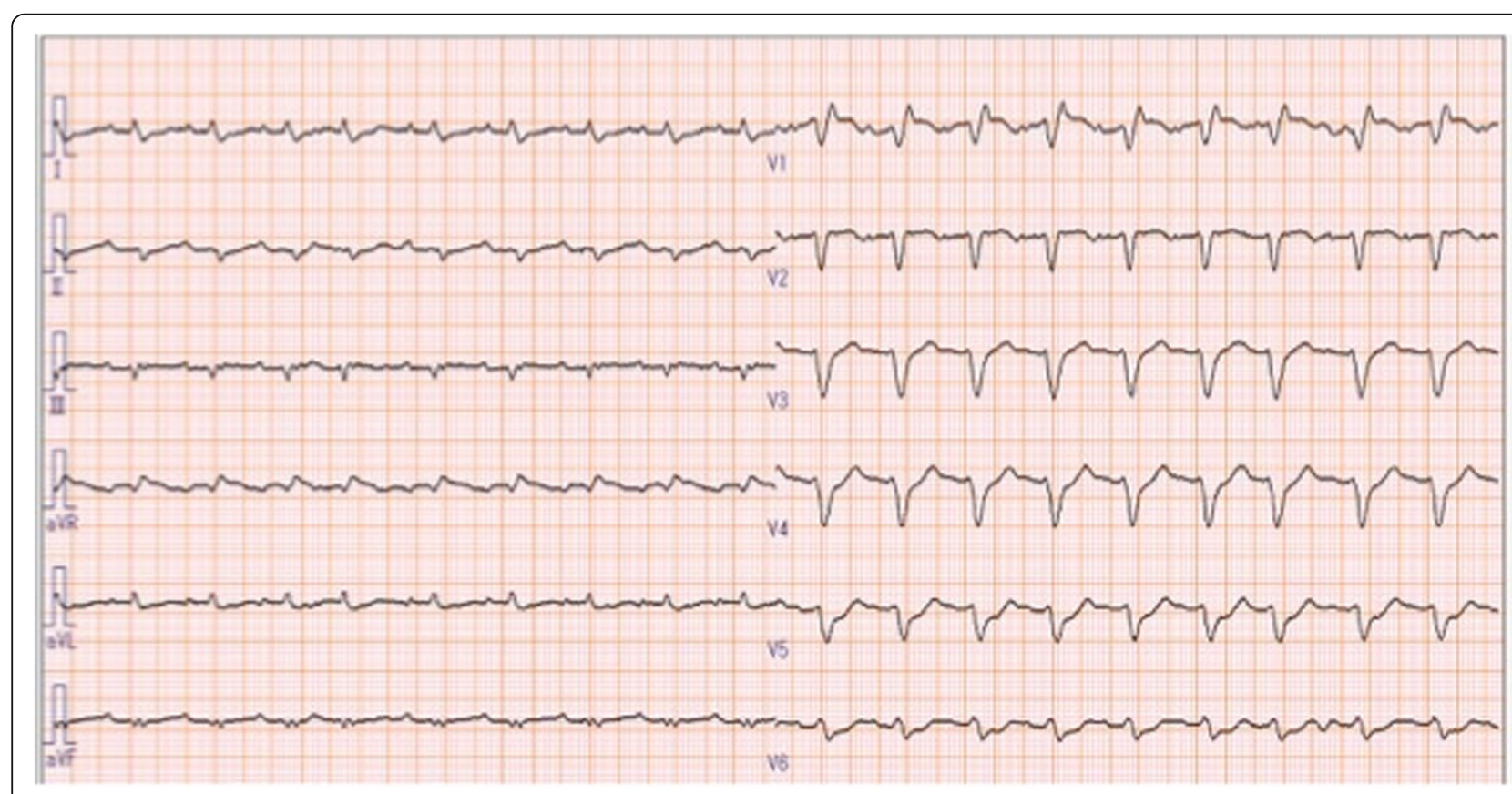

Fig. 1 The 12-lead electrocardiogram of the patient upon admission to the intensive care unit. Sinus rhythm, low-voltage R-wave, and intraventricular conduction disturbance in all leads were seen 
Table 1 The blood examination on admission and 1 and 10 days after the admission

\begin{tabular}{|c|c|c|c|}
\hline & Admission & $\begin{array}{l}1 \text { day after the admission } \\
\text { (after PCPS placement) }\end{array}$ & $\begin{array}{l}10 \text { days after the admission } \\
\text { (after intensive anticoagulant therapy) }\end{array}$ \\
\hline White blood cell counts $(/ \mu \mathrm{L})$ & 9200 & 9100 & 12,400 \\
\hline Hemoglobin $(\mathrm{g} / \mathrm{dL})$ & 10.2 & 10.6 & 10.7 \\
\hline Platelet counts $\left(\times 10^{4} / \mu \mathrm{L}\right)$ & 38.2 & 29.3 & 27.6 \\
\hline Total bilirubin (mg/dL) & 0.8 & 0.7 & 1.5 \\
\hline Aspartate transaminase (IU/L) & 401 & 431 & 194 \\
\hline Alanine aminotransferase (IU/L) & 403 & 367 & 236 \\
\hline Lactate dehydrogenase (IU/L) & 1081 & 926 & 932 \\
\hline Blood urea nitrogen (mg/dL) & 18 & 17 & 15 \\
\hline Creatinine (mg/dL) & 1.18 & 1.01 & 0.94 \\
\hline C-reactive protein $(\mathrm{mg} / \mathrm{dL})$ & 13.2 & 10.9 & 17.1 \\
\hline Creatine kinase (IU/L) & 1194 & 776 & 871 \\
\hline Creatine kinase-MB (IU/L) & 32 & 32 & 39 \\
\hline Troponin T (ng/dL) & 5.19 & - & - \\
\hline Brain natriuretic peptide $(\mathrm{pg} / \mathrm{mL})$ & 3035 & 2266 & - \\
\hline Lactate (mmol/L) & 1.20 & 1.12 & 0.97 \\
\hline $\mathrm{BE}(\mathrm{mmol} / \mathrm{L})$ & -0.2 & -0.1 & -1.3 \\
\hline International normalized ratio of prothrombin time & 1.14 & 1.16 & 1.21 \\
\hline Activated partial thromboplastin time $(\mathrm{s})$ & 30.0 & 38.7 & 118.9 \\
\hline Activated clotting time $(\mathrm{s})$ & 140 & 198 & 273 \\
\hline
\end{tabular}

Almost the normal ranges of coagulation test were found on admission. The marked prolonged activated partial thromboplastin time and activated clotting time were found after the intensive anticoagulation therapy for the intraventricular thrombus

was 2.4 L (approximately $400 \mathrm{~mL}$ of tidal volume and $6 /$ min of respiratory rate). After the initiation of the mechanical ventilation, his arterial blood gas analysis from the right radial artery showed a $\mathrm{pH}$ of 7.499, arterial oxygen tension $\left(\mathrm{PaO}_{2}\right)$ of $153 \mathrm{mmHg}$, and arterial carbon dioxide $\left(\mathrm{CO}_{2}\right)$ tension $\left(\mathrm{PaCO}_{2}\right)$ of $34.8 \mathrm{mmHg}$. And we started continuous infusion of propofol (1$2.5 \mathrm{mg} / \mathrm{kg} / \mathrm{h})$ and fentanyl $(40 \mu \mathrm{g} / \mathrm{h})$ for sedation. Then, we administered heparin (7000 IU) as an intravenous bolus, and his activated clotting time (ACT) was prolonged to $198 \mathrm{~s}$. We placed a venous cannula into the right atrium via the common right femoral vein and an arterial cannula into the left femoral artery and started the PCPS.

At the initiation of PCPS, the target value of PCPS blood flow was set at $3.0 \mathrm{~L} / \mathrm{min}$ (rotation speed of $3000 \mathrm{rpm}$ ), and the $\mathrm{F}_{\mathrm{I}} \mathrm{O}_{2}$ and total gas flow of the membrane oxygenator were set at 0.6 and $1 \mathrm{~L} / \mathrm{min}$, respectively.

And the intravenous continuous infusion of heparin (10,000 IU/day) was started in order to maintain his ACT within the range of 150 to $200 \mathrm{~s}$. After the PCPS blood flow reached to $3.0 \mathrm{~L} / \mathrm{min}$, the $\mathrm{SvO}_{2}$ increased to $66 \%$ and the total blood flow, which was the sum of PCPS blood flow and his own cardiac output, increased from 3.0 to $5.3 \mathrm{~L} / \mathrm{min}$ (Table 2 ).
Subsequently, we performed endomyocardial biopsy (EMB) followed by rapid microscopic examination, which showed the characteristic infiltration of multinucleated giant cells in the myocardium. He was eventually diagnosed with giant cell myocarditis (Fig. 2).

On the next morning, he developed complete atrioventricular block (Fig. 3), subsequent decreased blood pressure from $100 / 50$ to $70 / 40 \mathrm{mmHg}$, and increased pulmonary arterial pressure from $35 / 15$ to $60 / 20 \mathrm{mmHg}$. In addition, sudden elevation of $\mathrm{PaCO}_{2}$ from 31 to $62.5 \mathrm{mmHg}$ was also observed despite the preservation of both the steady PCPS output and the mechanical ventilation setting (Fig. 4 and Table 2). Hence, we performed transesophageal echocardiography (TEE), which indicated widespread thrombus formations and marked congestion in his left ventricular outlet tract and Valsalva sinus and closure of the aortic valve; however, there is no thrombus in his right ventricle (Fig. 5). Then, we checked ACT, which was $168 \mathrm{~s}$, and performed an additional test for heparin-induced thrombocytopenia (HIT) antibody, which we learned of the negative result later.

We increased the PCPS blood flow up to $3.5 \mathrm{~L} / \mathrm{min}$ and total gas flow up to $4.0 \mathrm{~L} / \mathrm{min}$, which lead to success of $\mathrm{CO}_{2}$ excretion, but his hemodynamic status remained unstable. After that, we started temporary cardiac pacing to treat complete atrioventricular block, which restored 
Table 2 Hemodynamic status of the patient on admission, before and after the initiation of PCPS, after the onset of complete atrioventricular block, and after ventricular pacing

\begin{tabular}{|c|c|c|c|c|c|}
\hline & Admission & $\begin{array}{l}\text { Before initiation } \\
\text { of PCPS }\end{array}$ & Initiation of PCPS & $\begin{array}{l}\text { Onset of } \\
\text { complete AVB }\end{array}$ & After ventricular pacing \\
\hline Respiratory support & $\begin{array}{l}\text { Face mask, } 5 \\
\mathrm{~L} / \text { min of oxygen }\end{array}$ & $\begin{array}{l}\text { Face mask, } 6 \\
\mathrm{~L} / \mathrm{min} \text { of oxygen }\end{array}$ & $\begin{array}{l}\text { APRV }, \mathrm{F}_{1} \mathrm{O}_{2}=0.6, \\
P_{\text {high }}=20 \mathrm{~cm} \mathrm{H} \mathrm{H}_{2} \mathrm{O}, \\
T_{\text {high }}=9.5 \mathrm{~s}, P_{\text {low }}=0 \mathrm{~cm} \\
\mathrm{H}_{2} \mathrm{O}_{1} T_{\text {low }}=0.5 \mathrm{~s}\end{array}$ & Same as on the left & $\begin{array}{l}\text { APRV, } \mathrm{F}_{1} \mathrm{O}_{2}=0.6, \\
P_{\text {high }}=15 \mathrm{~cm} \mathrm{H} \mathrm{H}_{2} \mathrm{O}, \\
T_{\text {high }}=5.5 \mathrm{~s}, P_{\text {low }}=0 \mathrm{~cm} \\
\mathrm{H}_{2} \mathrm{O}, T_{\text {low }}=0.5 \mathrm{~s}\end{array}$ \\
\hline $\mathrm{pH}$ & 7.531 & 7.532 & 7.449 & 7.272 & 7.554 \\
\hline $\mathrm{SaO}_{2}(\%)$ & 95.1 & 97.0 & 98.5 & 95.7 & 98.5 \\
\hline $\mathrm{PaO}_{2}(\mathrm{mmHg})$ & 75.4 & 97.0 & 153.0 & 100.8 & 158.0 \\
\hline $\mathrm{PaCO}_{2}(\mathrm{mmHg})$ & 25.5 & 28.1 & 34.8 & 62.5 & 27.3 \\
\hline $\mathrm{EtCO}_{2}(\mathrm{mmHg})$ & - & - & 21 & 41 & 17 \\
\hline $\mathrm{BE}(\mathrm{mmol} / \mathrm{L})$ & -0.2 & 1.7 & -0.1 & 0.3 & 1.9 \\
\hline Lac (mmol/L) & 1.2 & 1.3 & 1.12 & 1.03 & 1.28 \\
\hline $\mathrm{ABP}(\mathrm{mmHg})$ & $110 / 55$ & $112 / 42$ & $97 / 41$ & $70 / 40$ & $136 / 37$ \\
\hline PAP $(\mathrm{mmHg})$ & $37 / 18(26)$ & $28 / 11$ & $19 / 10$ & $60 / 20$ & $18 / 13$ \\
\hline PAWP (mmHg) & 25 & - & 12 & 30 & - \\
\hline RAP $(\mathrm{mmHg})$ & 18 & 18 & 12 & 18 & 8 \\
\hline $\mathrm{CO}(\mathrm{L} / \mathrm{min})$ & 3.60 & 3.80 & 2.3 & $<<1.0$ & 1.3 \\
\hline Output of PCPS (L/min) & - & - & 3.0 & 3.0 & 3.5 \\
\hline $\begin{array}{l}\text { The sum of PCPS blood flow and } \\
\text { his own cardiac output (L/min) }\end{array}$ & 3.60 & 3.80 & 5.3 & 3.0 & 4.8 \\
\hline Total gas flow of oxygenator ( $\mathrm{L} / \mathrm{min})$ & - & - & 1.0 & 1.0 & 4.0 \\
\hline $\mathrm{SvO}_{2}(\%)$ & 40 & 39.7 & 66 & 55 & 69 \\
\hline
\end{tabular}

The cardiogenic shock was improved by the PCPS support. After the onset of complete AV block, significant decrease of CO, pulmonary congestion, and increased $\mathrm{PaCO}_{2}$ were observed

PCPS percutaneous cardiopulmonary support, $A V B$ atrioventricular block, $A P R V$ airway pressure release ventilation, $F_{1} O_{2}$ fraction of inspired oxygen, $P_{\text {high }}$ high continuous positive airway pressure, $T_{\text {high }}$ duration of $P_{\text {high, }}, P_{\text {low }}$ low continuous positive airway pressure, $T_{\text {low }}$ duration of $P_{\text {low, }} E t C \mathrm{EO}_{2}$ end-tidal carbon dioxide tension, $\mathrm{PaCO}_{2}$ arterial carbon dioxide tension, $A B P$ arterial blood pressure, $P A P$ pulmonary artery pressure, $P A W P$ pulmonary artery wedge pressure, $R A P$ right atrial pressure, $\mathrm{CO}$ cardiac output, $\mathrm{SVO}_{2}$ mixed venous oxygenation saturation

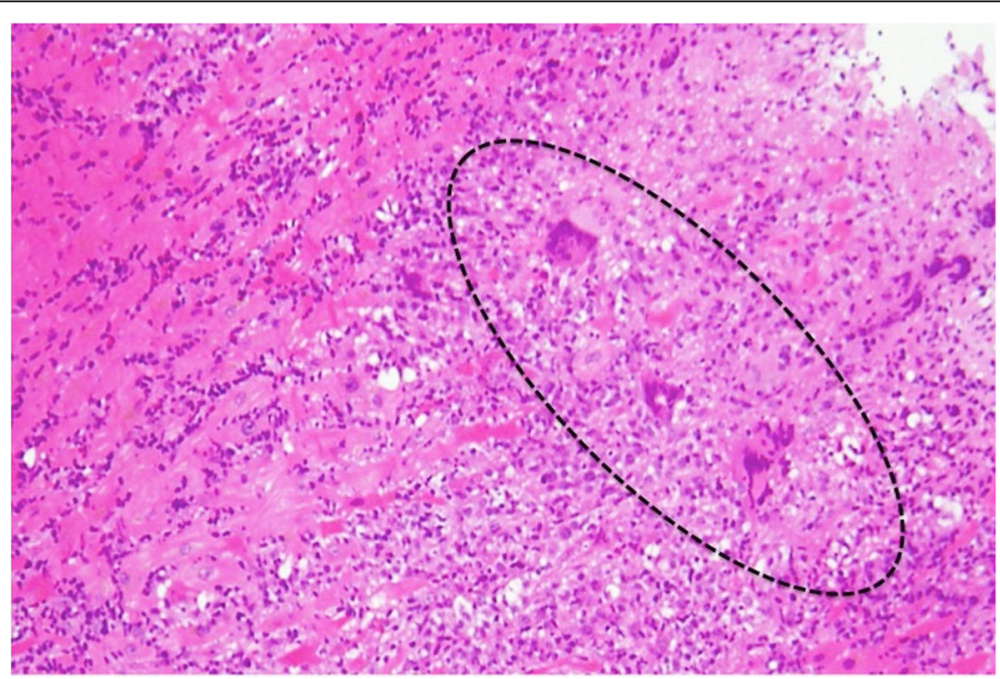

Fig. 2 Microscopic examination from the endomyocardial biopsy of the right ventricle. Characteristic infiltrations of multinucleated giant cells in the myocardium (open circle) were seen 


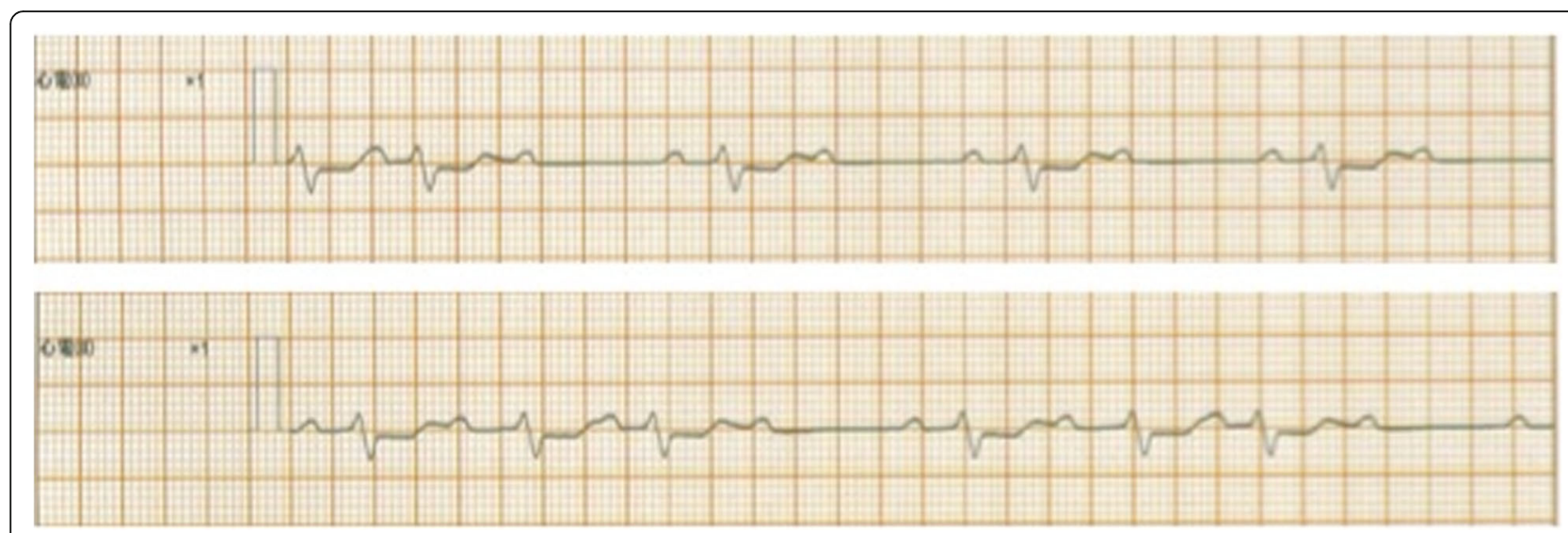

Fig. 3 Electrocardiogram strips on the next morning. Complete atrioventricular block was seen

his left ventricular contractility, opened the aortic valve, and subsequently washed out the thrombus.

Thereafter, for the purpose of preventing further thrombus formation, anticoagulant therapy was intensified (20,000 IU/day of heparin) to maintain ACT within the range of 200 to $240 \mathrm{~s}$. Ten days after the admission, his ACT was markedly prolonged up to $273 \mathrm{~s}$ (Table 2) and he presented with an anisocoria. Therefore, we performed a computed tomography (CT) scan of the brain, which revealed the intracranial hemorrhage. He did not recover from the heart failure and died 16 days after the admission.

\section{Discussion}

Giant cell myocarditis is characterized by infiltration of multinucleated giant cells in the myocardium and distinguished from cardiac sarcoidosis by the absence of noncaseous necrosis. Cardiac sarcoidosis is generally associated with extracardiac lesions and progresses slowly, whereas giant cell myocarditis develops and progresses to heart failure rapidly, which results in poor prognosis [1-3]. An accurate data about the morbidity of giant cell myocarditis has not been shown because the pathological diagnosis of the disease is difficult. However, approximately 100 cases were reported despite the rarity of this myocarditis type

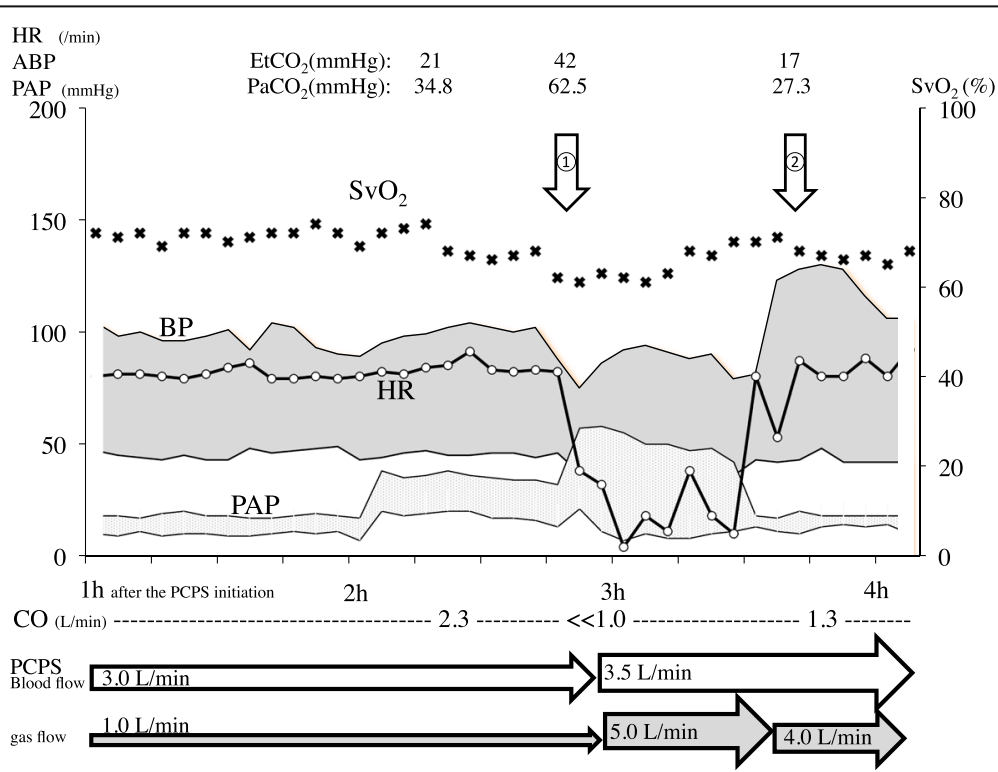

Fig. 4 The change in the hemodynamic status around the onset of the atrioventricular block. HR heart rate, $A B P$ arterial blood pressure, $P A P$ pulmonary artery pressure, $P_{E} t \mathrm{CO}_{2}$ end-tidal carbon dioxide tension, $\mathrm{PaCO}_{2}$ arterial carbon dioxide tension, $\mathrm{SVO}_{2}$ mixed venous oxygenation saturation, PCPS percutaneous cardiopulmonary support, CO cardiac output. (1) The onset of the complete atrioventricular block. (2) The start of the ventricular pacing. After the onset of the complete atrioventricular block, the decrease of BP and the increase of PAP and $\mathrm{PaCO}_{2}$ continued until the point when the blood flow and the gas flow of the PCPS were augmented. The hemodynamics of the patient improved along with the recovery of the ventricular contraction by the ventricular pacing 


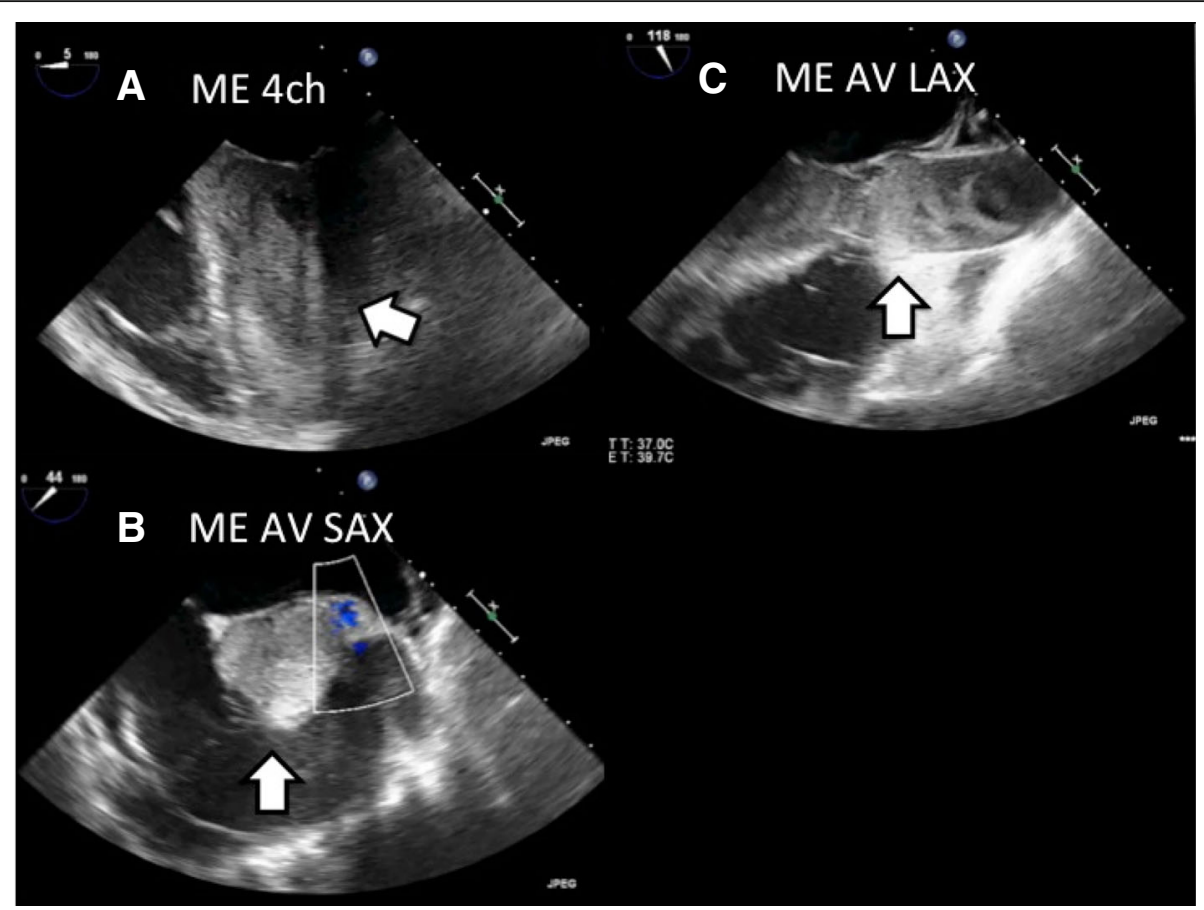

Fig. 5 Transesophageal echocardiography (TEE) after the onset of atrioventricular block. a Mid-esophageal 4-chamber (ME 4ch) view showed thrombus formations and congestion in the left ventricle. $\mathbf{b}$ Mid-esophageal aortic valve short-axis (ME AV SAX) view showed thrombus formations in the Valsalva sinus and aortic valve closure. c Mid-esophageal long-axis (ME AV LAX) view showed thrombus formations in the left ventricular tract and the Valsalva sinus

[4]. Mechanical circulatory support, such as IABP and/or PCPS as well as inotropes, is required for the treatment of acute giant cell myocarditis because the disease often progresses to fulminant myocarditis. Some reports showed the efficacy of immunosuppressive therapy for giant cell myocarditis, which suggested a relationship between giant cell myocarditis and autoimmune reaction [5-7]. In addition, a multicenter study of immunosuppressive therapy for giant cell myocarditis showed the prolonged median transplant-free survival from 3 to 12.3 months [1]. However, some studies also showed that few patients recovered from heart failure and weaned from mechanical circulatory support [7-9]. The patients of that study eventually required heart transplantation or circulatory support, such as ventricular assist device (VAD) for destination therapy. In Japan, VAD is a practical option for the rescue treatment of chronic giant cell myocarditis because only 40 heart transplantations are performed per year, and the mean waiting period for transplantation is 636 days. We need to transfer the patients to the hospital capable for left VAD (LVAD) surgery, which is limited in Japan, if needed for LVAD placement.

We could not save this patient because of the disease progression and the complications, including the thrombosis due to the congestion of the left ventricle and intracranial hemorrhage due to the intensive anticoagulant therapy to prevent thrombosis.
Myocarditis alone rarely accompanies ventricular thrombosis unlike dilated cardiomyopathy. Left ventricular distension strongly contributes to intraventricular thrombosis. Therefore, the cornerstone in prevention of intraventricular thrombosis is systemic anticoagulant therapy and prevention of left ventricular distension. In this case, thrombotic tendency was induced by the left ventricular congestion due to decreased left myocardial contractility. Regardless of promoting the left ventricular ejection by inotropic agents and IABP, adequate cardiac output was not obtained, which resulted in the placement of PCPS. However, peripheral PCPS perfused the aortic root retrogradely, which caused the increase of left ventricular afterload, the subsequent distension of the left ventricle, and the further increase of thrombotic tendency and congestion at the left ventricular outlet tract. Approximately $15 \%$ of patients with giant cell myocarditis are associated with atrioventricular block $[1,4]$. In this case, the complete atrioventricular block induced a critical decrease of the left ventricular ejection, which resulted in the further left ventricle distension, which might trigger the thrombosis (Fig. 6).

Before the onset of the atrioventricular block, the patient had $2.3 \mathrm{~L} / \mathrm{min}$ of the pulmonary circulation with $2.4 \mathrm{~L} / \mathrm{min}$ of minute volume of ventilation and $3.0 \mathrm{~L} / \mathrm{min}$ of the PCPS blood flow with $1 \mathrm{~L} / \mathrm{min}$ of gas flow of the artificial lung. In this condition, the main pathway of his 


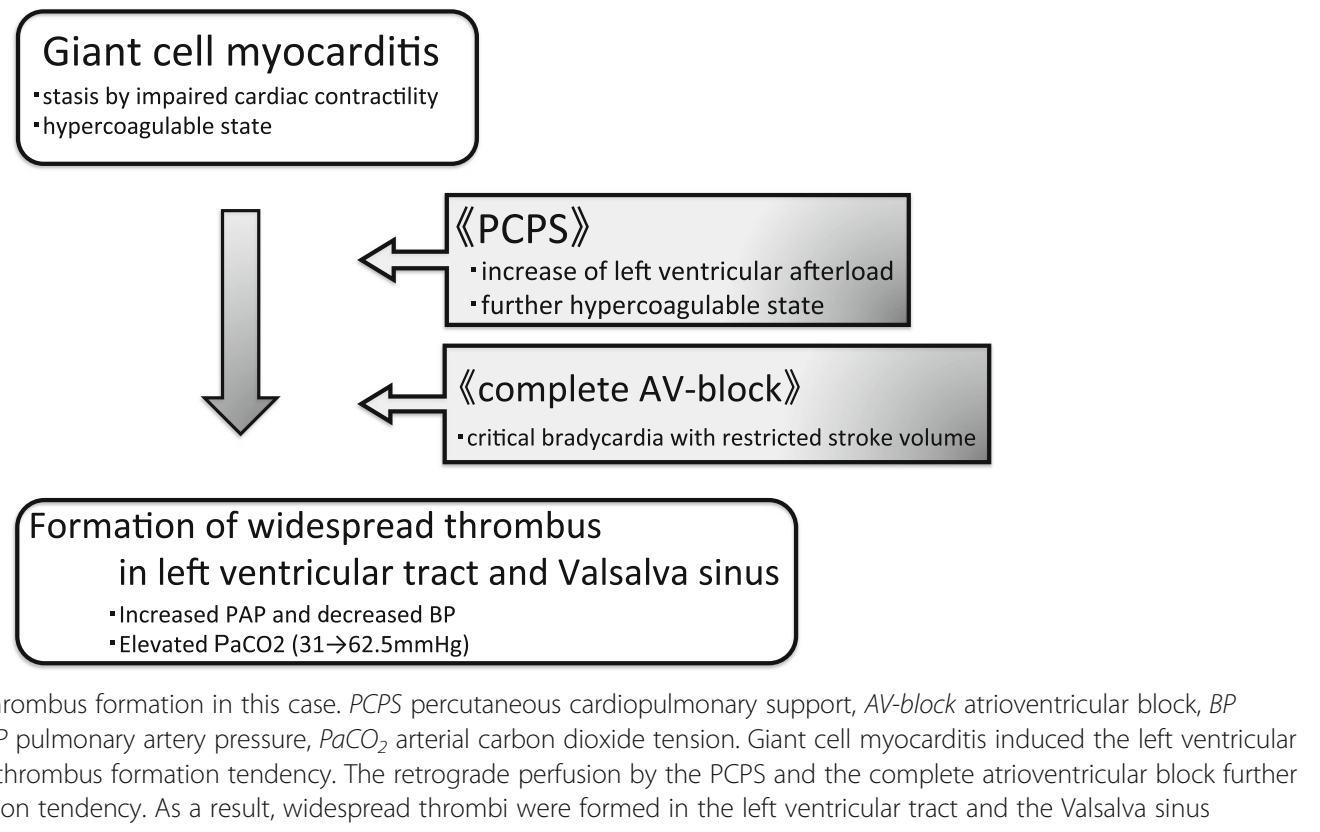

$\mathrm{CO}_{2}$ elimination was thought to be the pulmonary circulation. After the onset of the atrioventricular block, the pulmonary circulation decreased to far less than $1.0 \mathrm{~L} / \mathrm{min}$ because of the loss of the cardiac output while $3.0 \mathrm{~L} / \mathrm{min}$ of the PCPS blood flow was maintained. Hence, the total lung blood flow decreased to approximately $3.0 \mathrm{~L} / \mathrm{min}$, and the artificial lung ought to excrete almost whole $\mathrm{CO}_{2}$. However, the gas flow of the artificial lung remained $1.0 \mathrm{~L} / \mathrm{min}$, which might be too little to excrete sufficient amount of the $\mathrm{CO}_{2}$. Thereafter, the $\mathrm{PaCO}_{2}$ of the patient rose from 34.8 to $62.5 \mathrm{mmHg}$.

To our knowledge, no guideline is available for treatment of intraventricular thrombosis in PCPS patients. The treatment choices are thrombectomy and intensive anticoagulant therapy [10-12]. Because of the unstable circulatory status of the patient, intensive systemic anticoagulant therapy and temporary cardiac pacing, which could recover the ventricular contractility and ejection, were the possible choices. Therefore, we started temporary cardiac pacing, which recovered the left ventricular contractility, opened the aortic valve, and washed out the thrombi. Additionally, the efficacy of local thrombolysis in intraventricular thrombosis was recently reported. This technique might be effective in this case [13].

The washed out thrombi formed at the onset of the complete atrioventricular block could cause cerebral infarctions, and the intensified coagulation therapy might deteriorate the cerebral infarctions into the intracranial hemorrhage. At the onset of complete atrioventricular block, we did not perform a CT scan of the brain or awaken him from the deep sedation due to his unstable circulatory status. But 10 days after the admission, we performed a CT scan of the brain at the risk of circulatory failure because the patient presented with an anisocoria. However, we could not identify the true pathogenesis of the intracranial hemorrhage.

Different types of myocarditis show different clinical courses and prognoses and require different treatments. Therefore, EMB, identifying the histological type of myocarditis, should be performed as the patient's condition permits. In this case, multidrug immunosuppressive therapy was started after the histological diagnosis of giant cell myocarditis. However, as previously described, heart transplantation or VAD may be required for a definitive therapy within months or years. LVAD, withdrawing the blood from the left ventricular apex and returning the blood to the ascending aorta, can establish physiological perfusion and reduce left ventricular volume, whereas peripheral PCPS perfuses aorta retrogradely, increases left ventricular afterload, and might induce left ventricular distension. In addition, LVAD can cause less bleeding complications than PCPS because LVAD requires weaker anticoagulation than PCPS [14]. If we could place an LVAD on the patient at the diagnosis of giant cell myocarditis, complications such as thrombosis and bleeding might be prevented, which might result in smooth bridge to heart transplantation. To improve the prognosis of myocarditis, full knowledge of the clinical course of myocarditis, precise diagnosis, transfer to an advanced medical center where LVAD placement can be performed and rapid establishment of adequate mechanical circulatory support should be required. 


\section{Conclusions}

We present a patient with giant cell myocarditis who developed widespread thrombosis in the left ventricle during PCPS support. Retrograde perfusion by PCPS and complete atrioventricular block promoted left ventricular distension, reduced left ventricular ejection, and caused widespread thrombosis. In the circulation management of patients with giant cell myocarditis, we should rapidly establish physiological mechanical circulatory support.

\section{Abbreviations}

ACT: Activated clotting time; $\mathrm{CO}$ : Cardiac output; $\mathrm{CO}_{2}$ : Carbon dioxide; CPAP: Continuous positive airway pressure; CT: Computed tomography; EMB: Endomyocardial biopsy; $\mathrm{F}_{1} \mathrm{O}_{2}$ : Fraction of inspired oxygen; HIT: Heparininduced thrombocytopenia; IABP: Intra-aortic balloon pumping; LVAD: Left ventricular assist device; $\mathrm{PaCO}_{2}$ : Arterial carbon dioxide tension; $\mathrm{PaO}_{2}$ : Arterial oxygen tension; PAP: Pulmonary arterial pressure; PCPS: Percutaneous cardiopulmonary support; $\mathrm{SvO}_{2}$ : Mixed venous oxygenation saturation; TEE: Transesophageal echocardiography; VAD: Ventricular assist device

\section{Authors' contributions}

$Y T, K T$, and TO were anesthesiologists attending to the intensive care. $Y T$ drafted the manuscript. YE, HT, and MY supervised the treatment and helped to draft the manuscript. All authors read and approved the final manuscript.

\section{Authors' information}

YT, KT, and TO are M.D. and Stuff Anesthesiologists of the Department of Anesthesiology, Tohoku University Hospital. HT is M.D., PhD., and a Lecturer of the Department of Anesthesiology, Tohoku University Hospital. YE is M.D., PhD., and the Associate Director of the Department of Surgical Center and Supply, Sterilization, Tohoku University Hospital. MY is M.D., PhD., and a Professor of Anesthesiology and Perioperative Medicine, Tohoku University School of Medicine.

\section{Competing interests}

The authors declare that they have no competing interests.

\section{Consent for publication}

Written informed consent was obtained from the patient's family for publication of this case report and any accompanying images. A copy of the written consent is available for review by the Editor-in-Chief of this journal.

\section{Author details \\ 'Department of Anesthesiology, Tohoku University Hospital, 1-1 Seiryomachi, Aoba-ku, Sendai 980-8574, Japan. ${ }^{2}$ Division of Surgical Center and Supply, Sterilization, Tohoku University Hospital, 1-1 Seiryomachi, Aoba-ku, Sendai 980-8574, Japan. ${ }^{3}$ Anesthesiology and Perioperative Medicine, Tohoku University School of Medicine, 2-1 Seiryomachi, Aoba-ku, Sendai 980-8575, Japan.}

Received: 3 August 2016 Accepted: 18 November 2016

Published online: 29 November 2016

\section{References}

1. Cooper Jr LT, Berry GJ, Shabetai R. Idiopathic giant-cell myocarditis-natural history and treatment. Multicenter Giant Cell Myocarditis Study Group Investigators. N Engl J Med. 1997;336:1860-6.

2. Shirani J, Freant $\sqcup$, Roberts WC. Gross and semiquantitative histologic findings in mononuclear cell myocarditis causing sudden death, and implication for endomyocardial biopsy. Am J Cardiol. 1993;72:952-7.

3. Blauwet LA, Cooper LT. Idiopathic giant cell myocarditis and cardiac sarcoidosis. Heart Fail Rev. 2013:18:733-46.

4. Cooper LT. Giant cell and granulomatous myocarditis. Heart Fail Clin 2005;1:431-7.

5. Menghini W, Savecenko V, Olson $\sqcup$, Tazelaar HD, Dec GW, Kao A, Cooper Jr LT. Combined immunosuppression for the treatment of idiopathic giant cell myocarditis. Mayo Clin Proc. 1999;74:122-6.
6. Levy NT, Olson L, Wayand C, Brack A, Tazelaar HD, Edwards WD, Hammill SC. Histologic and cytokine response to immunosuppression in giant-cell myocarditis. Ann Intern Med. 1998;128:648-50.

7. Steinhaus D, Gelfand E, Vanderlaan PA, Kociol RD. Recovery of giant-cell myocarditis using combined cytolytic immunosuppression and mechanical circulatory support. J Heart Lung Transplant. 2014;33:769-71.

8. Ankersmit HJ, Ullrich R, Moser B, Hoetzenecker K, Hacker S, German P, Krenn C, Horvat R, Grimm M, Wolner E, Zuckermann A. Recovery from giant cell myocarditis with ECMO support and utilisation of polyclonal antihymocyte globulin: a case report. Thorc cardiovasc Surg. 2006;54:278-80.

9. Marelli D, Kermani R, Bresson J, Fishbein MC, Hamilton M, Moriguchi J, Fonarow GC, Cohen B, Kobashigawa J, Laks H. Support with the BVS 5000 assist device during treatment of acute giant-cell myocarditis. Tex Heart Inst J. 2003;30:50-6.

10. Kuhl T, Wendt S, Langebartels G, Kröner A, Wahlers T. Recurrent left atrial and left ventricular thrombosis due to heparin-induced thrombocytopenia: case report and short review. Thorac Cardiovasc Surg. 2013;61:537-40.

11. Moubarak G, Weiss N, Leprince P, Luyt CE. Massive intraventricular thrombus complicating extracorporeal membrane oxygenation support. Can J Cardiol. 2008:24:e1.

12. Ramjee V, Shreenivas S, Rame JE, Kirkpatrick JN, Jagasia D. Complete spontaneous left heart and aortic thrombosis on extracorporeal membrane oxygenation support. Echocardiography. 2013;30:E342-3.

13. Sangalli F, Greco G, Galbiati L, Formica F, Calcinati S, Avalli L. Regional thrombolysis with tenecteplase during extracorporeal membrane oxygenation: a new approach for left ventricular thrombosis. J Card Surg. 2015:30:541-3.

14. Menon AK, Götzenrich A, Sassmannshausen H, Haushofer M, Autschbach R, Spillner JW. Low stroke rate and few thrombo-embolic events after HeartMate II implantation under mild anticoagulation. Eur J Cardiothorac Surg. 2012:42(2):319-23.

\section{Submit your manuscript to a SpringerOpen ${ }^{\circ}$ journal and benefit from:}

- Convenient online submission

- Rigorous peer review

- Immediate publication on acceptance

- Open access: articles freely available online

- High visibility within the field

- Retaining the copyright to your article

Submit your next manuscript at $>$ springeropen.com 